\title{
Joyful Motherhood: A New Approach in the Mexican Literature Written by Women
}

\author{
Cándida Elizabeth Vivero Marín \\ Gender Studies Center, University of Guadalajara, Guadalajara, Mexico \\ Email: elizabeth_vivero@hotmail.com
}

How to cite this paper: Marín, C. E. V. (2020). Joyful Motherhood: A New Approach in the Mexican Literature Written by Women. Open Journal of Social Sciences, 8 , 337-351.

https://doi.org/10.4236/jss.2020.86026

Received: April 29, 2020

Accepted: June 14, 2020

Published: June 17, 2020

Copyright $\odot 2020$ by author(s) and Scientific Research Publishing Inc. This work is licensed under the Creative Commons Attribution International License (CC BY 4.0).

http://creativecommons.org/licenses/by/4.0/

(c) (i) Open Access

\begin{abstract}
In recent years, the generation of female writers who were born in the 1980s addresses the motherhood subject from a joyful perspective, including the exhausting aspects of it. This paper aims to study Daniela Rea's text Mientras las niñas duermen [While the girls are asleep], from a feminist and gender perspective in order to point out a new perspective about the subject in Mexican literature written by women.
\end{abstract}

\section{Keywords}

Being-Mother, Motherhood, Criticism, Joy, Bliss

\section{Introduction}

In Mexican narrative written by women born in the 1980s, motherhood begins to be appreciated as a happy, joyful motherhood, filled with enthusiasm, even when preserving its shares of disillusionment and thwarting. Such is the case of Daniela Rea, who shares her experiences regarding motherhood through an intimate journal. Rea's text shows a new approach to the subject with a clear and concise prose which connects but also sets the difference with the Mexican literature tradition written by women as we establish in the first part of this paper.

So, this new notion of motherhood described by young female writers stands out, precisely, because of the paradigm shift around being a mother, as their previous generation colleagues envisage motherhood from the professionalization point of view, which enables them to obtain the portion of freedom that is lost when becoming mothers.

This paper will, therefore, analyze this new approach to motherhood as one that is intended, wanted, wished and embraced, instead of being an infliction or coercion wielded by the patriarchal system. The paper is divided into four parts: 
the first one (as we have said before) sets the difference between the Mexican female literature and the Rea's proposal; the second, sets the continuity of Rea's work with the awaking texts which are considered feminist; the third refers Rea's diary to the new paradigm: joyful motherhood; and the fourth describes the relationship between the personal and the professional life from a gender perspective.

\section{Criticism towards the Motherly Ideal}

In literature written by women, motherhood is a recurring topic. As it is studied by many scholars (Olga Martha Peña Doria, Rosa María Gutiérrez, Adriana Sáenz Valadez, Aralia López González, Ana Rosa Domenella, among others), motherhood is a main subject in the Mexican criticism. So, motherhood is linked to a critical view around the female ideal that assumes the representation of the being-mother as someone selfless, submissive and constantly given to others. Thus, in the Mexican female writers' literature, and specifically on that of the young female authors who were born in the late 1960s, the critical perspective is accomplished through a realistic view. In these texts, the mother-daughter relationship is very close. Also, whenever there is a continuous struggle to exert power or to break free from it, a dichotomy of bonds can be observed: the first one, harmonious, the second, conflictive.

Therefrom, the mother-daughter relationship is crucial in the context in hand, as the mother figure continues to be reinforced by several media in Mexico creating, at times, a "mother excess". Such excess results from the father's absence, hence shaping, as appointed by Santiago Ramírez (as cited in López González, 1995: p. 205) a uterine culture, typified by an "outpouring of love" during Mother's day. Notwithstanding social importance and relevance mothers have, young female writers turn down this paradigm in their representations, as they appeal to realistic images of mothers that are either absent or quite empowered and will not subordinate to the maternal role assigned by society. By contrast, they escape such ideal and act as entities that are free to practice a profession and their sexuality, as many publications of female Mexican writers born in the 1970s portray. A good example is Itzel Guevara del Ángel's storybook: Santas madrecitas [Holy Little Mothers] (Guevara del Ángel, 2008).

In this manner, the figure of the mother in this recent literature dissociates from the collective imaginary in order to place itself in an even more complex representation level that evidences a crisis around the mother's heteropatriarchal ideal. Not yet achieving a full transformation, it is to be noted that a shift in paradigm around traditional frameworks has started, as an entire pleiad of female writers (Cecilia Eudave, Guadalupe Nettel, Itzel Guevara del Ángel, Criseida Santos Guevara, among others) addresses this topic from a harsh perspective, bringing to stage female characters that are more concerned about their own interests, instead of attending to the affective and emotional needs of their sons and daughters. We can appreciate such cases in Cecilia Eudave's novel Bestiaria vida [Bestiary life] (Eudave, 2008) or Itzel Guevara's Santas madrecitas storybook, to mention a couple of examples. 
Motherhood, and its practice, is brought into discussion by young Mexican female writers. In their descriptions, we can appreciate that the bond established with the mother tends to be more negative than positive, which fully meets Emilie L. Bergman's statement, namely, the denial of what is motherly, whilst underscoring autonomy as the foundation of the modern masculine identity (Bergman, 1995: p. 34). In accordance with this autonomy, a subjective sign of freedom is created, resulting in the ethical self-realization within the private life sphere, which is translated in the political creation of collective will (Habermas, 2008: p. 99). The mother, what is motherly and motherhood are relegated to a second place and, in the case of female writers, the tight bond between mother-son/daughter is either denied or canceled whenever the mother characters fail to accept their traditional roles. We can then observe that, in recent Mexican narrative, motherhood is not undertaken in a joyful way. On the contrary, it is undertaken with discomfort before the impending sacrifice entailed by the practice of motherhood itself. That is the case, for instance, of Bestiaria vida, where motherhood is depicted in negative terms and even harmful to children's emotional and mental health. In it, the character that represents the mother is described as a basilisk, capable of emasculating the father due to his economic and work-related empowerment, which results in the rupture of the family connections, and even leading to the main character's lack of safety and self-esteem:

[...] she was hard-working, organized and, in addition, successful. She earned money in abundance and, so far, we don't know what became of it. I always felt afraid of her [...] It was well known that, just by talking to anyone, my mother would make them become furious, depressed and downhearted. No maid was able to stand her presence, nor a gardener or a cook [...] Maybe [the father] had to leave because there was not a single place in the house that belonged to him. (Eudave, 2008: pp. 16, 17) ${ }^{1}$

Something similar happens in the stories that comprise Santas madrecitas volume, where we can see the mother characters fighting their daughters for the love of men. As the mothers have lost their youth and beauty, they find themselves eager to obtain sexual-affective attention. This is the reason why stories such as Bambi and Emperatrices depict the maternal-filial relationship in negative terms, as their children (in this case, their daughters) are not able to satisfy the public recognition desires that their mothers also long for. Moreover, the first story implies an incestuous relationship when expressing that both figures, mother and daughter, not only end up sharing Juanjo, their boyfriend, but they also share the Father: "Bambi loves Mother deeply, she understands her. She does not care sharing Juanjo, just as Mother does not care sharing Father whenever he comes to visit." (Guevara del Ángel, 2008: p. 45).

However, and notwithstanding the conflict that could arise from the revelation of this situation, the storytelling continues its course until the end without ${ }^{1}$ Translator's Note: All the translations of citations by Susana I. Sevilla Beltrán, unless otherwise noted. 
any setbacks, as the attitude of both Bambi and her Mother seems to be justified by the love they share and the complicity established when the mother yields the spotlight to her daughter, as she is younger and prettier. Hence, in this story, maternity is shown as "deviated" or out of the traditional standards, as the mother figure does not assume her role as a sexually-passive woman. Instead, she satisfies her sexual needs, and the unequivocal rupture of the incest taboo represents no conflict to her, as it results in the enjoyment shared both with the Father, and with Bambi's boyfriend who, young as he is, could be considered her son.

As a matter of fact, in Bambi story, the traditional mother role is not practiced either, as it breaks the mother's idealized behavior and established patterns whilst maternal love is distorted and altered. Therefore, everything that could be considered as a distinctive or typical trait of a Good Mother, because of such underlying perversion, ends up being a kind of love that is skewed, incestuous and, therefore, wicked. The ease with which the female characters assume this situation strengthens the mother-daughter relationship, as it is based in a downright complicity. Bambi and Mother (name after which we know the character) transform themselves in a nearly indivisible binomial in order to keep their secret, that is clearly disturbing, but leads them to create truly tight bonds that are translated into a solid friendship, expressed through the consolidation of their presence in the high circles of Veracruz's society: "Bambi and Mother have a busy schedule, as required by Veracruz's high society: charity dinners, openings, Sunday mass, not to mention cultural events." (Guevara del Ángel, 2008: p. 42).

Bambi and Mother's gentrification, revealed halfway through the story, strengthens the sense of silence and complicity, as it reduces the dreadful double standard that distinguishes Mexico's high-society sector. Bambi and her mother are, therefore, a portrait of the perversions that are practiced day by day by certain sectors and that are concealed through complicities based on love misconceptions.

On the other hand, Emperatrices story once more brings up the topic of the mother's practice of sexuality. However, different from the previous story, this chronicle depicts how the mother-daughter relationship is broken as a result of the poor or null understanding between them. Affective detachment is born from the sepulchral silence with which both of them hide the desire to observe (mother's voyeurism) and being observed (the daughter's desire). They both know, somehow, that the mother observes behind the curtain every time the daughter has sexual intercourse inside her lover's car, who is a married man called Roberto. They also know how the mother enjoys watching them and smelling her daughter's intimate garments after making love. However, as it would happen on the previous story, none of them will talk about or mention what happened. As their maternal-filial relationship is tense, the scenario where this perverse behavior takes place is also tense in return. Thereby, as everything happens in a perverse manner, the ideal mother-daughter image is broken and it is then not surprising that the actions of the story take place in the dark and in 
enclosed spaces: "In the dark, in the bedroom she shares with her mother [...]. An infuriating brightness that increasingly opposes to the outside darkness [...]. The car $[\ldots]$ protected by the moonless, overcast night $[\ldots]$, she enters the bedroom and starts undressing silently, in the shadows." (Guevara del Ángel, 2008: pp. 66-68).

Both main characters keep their complicity underground, revealing the mother's permissibility when accepting the adulterous relationship her daughter sustains. Such fact, which entails a double standard, contrasts with the excessive care with which Emperatriz (the mother) treats Emperatriz (the daughter) by performing caregiving actions, like cooking for her daughter and walking her to the bus stop to ensure everything is fine. Similar to the previous story, this double standard emphasizes perversion and reinforces the complicity between the female characters but, different from the first story, in Emperatrices such complicity is not portrayed as a friendship. Instead, it is a need sine qua non the mother-daughter relationship would not be sustained. Were it not for this silence, both characters would have broken the bond that kept them together, as their relationship had worn out without us truly knowing the cause of such erosion: "Exhausted [Emperatriz, the daughter], she enters her bedroom, lies down on the bed and closes her eyes [...] She knows her mother pretends to be asleep and she, as well, pretends to believe it. But then again that is also part of their routine. The routine they have lived in for years." (Guevara del Ángel, 2008: pp. 67-68).

In this sense, in Emperatrices story, we can observe motherhood from a perverse connotation. Not because the mother practices her sexuality, but because she unleashes her sexual fantasies (voyeurism) without her daughter's explicit approval. This silent agreement between both characters, what is more, conducted in the dark, develops a tense, almost suffocating environment that captures the readers and introduces them in an underground atmosphere that exacerbates the sense of what is forbidden, thus creating a sui generis atmosphere that allows us witnessing the disturbed passions of both characters. While doing so, we are placed in the same position that Emperatriz (the mother) holds: along with her, we become voyeurists.

In such a way, as we can see, the mother and motherhood figure are introduced by aspects that are different from those traditional and ideal. The writings represent women that lack of, and long for, either public or family recognition. In any case, they claim for themselves action spaces where they can practice their leadership (this is the case of Bestiaria vida) or their sexuality (as it happens in Bambi and Emperatrices stories). Along with this need of taking ownership of a place, the aforementioned frictions and complicities arise. As a result, mothers escape from the heteronormative ideal in order to act differently, by breaking the Good Mother's image and practicing, wherever possible, their action capacity.

In such a way, when the paradigm of the selfless mother willing to sacrifice for her children is broken, Kemy Oyarzún's statement around female writing is met, namely, the rupture of the joyful mirror of maternal writing (Oyarzún, 1995: p. 
56). According to Oyarzún, the conflict with the mother results from denying the own gender-sexual difference:

The girl's phobia against her mother is translated in misogyny's internationalization. Either I am myself (between the void in the gender-sexual constellation), or a woman (i.e., I am still affiliated to the mother, incest, homosexuality, madness). Individualization of the individual-man as a man becomes the standard. On its behalf, the mere individualization of the woman as a woman represents an infringement. It is possible to be both a man and a person, but, in this context, being a woman and a person implies a systematic outage. (Oyarzún, 1995: p. 58)

As rightly stated by Cristina Palomar, the Good Mother denies or cancels her deepest desires for the sake of devoting herself to the proper care and upbringing of her children. Such annulment must be experienced through joy, as she is required to live a selfless acceptance. As Oyarzún states, the mother-woman is required to settle with the invalidation of her being a person, as the good mother is conceived as a woman that is constantly concerned for her sons and daughters. Thus, as Palomar points out, there would not be such thing as bad mothers, but mothers who are not properly placed or who are in the wrong position. Hence, the mother's figure entails a wide range of values and symbolic-discursive significances reflecting the maternal ideal linked to instinct which, incidentally, has been challenged by many feminists around the world, including Elisabeth Badinter (1981). In this idealized context there is an attribution of a series of traits and features like the "maternal instinct, motherly love, motherly savoir faire and a long series of virtues resulting from the following elements: patience, tolerance, comforting capacity, healing capacity, the ability to nurse, to attend to, to listen to, to protect, to sacrifice oneself, etc." (Palomar Verea, 2007: p. 58).

The woman-mother is linked to this long list of attributes and she must accept to comply with them, otherwise, she will be destined to punishment, even when this punishment is symbolic:

Those who ignore this trend will be strictly punished by the sense of guilt [...] "bad mothers" are [turned into] a strange body: a tangible enemy against which it is possible to fight and which is also expected to be conquered through re-education, readapting and standardization training mechanisms. (Palomar Verea, 2007: p. 60)

From this traditional perspective, as we have highlighted before, bad mothers are relocated through reeducation, which normalizes their behavior and readjusts their focus of attention towards their progeny, their upbringing and care. The misplaced woman-mother is reoriented in her affection and is once more set in place in the heteropatriarchal order she needs to abide by, without major questioning. Therefore, the mothers we referred to in the cited examples represent misplaced mothers that, notwithstanding their empowerment, in the end undergo the punishment of being their daughters' subordinates (Bambi and 
Emperatrices) or that of the lack of their children's affection (Bestiaria vida). Be that as it may, in both cases the mother characters suffer the consequences of age, and the alleged harmony they are able to establish with their daughters is the result of such characters finally accepting and assuming they are old, decrepit women, praising and accepting their daughters' beauty and youth. For this reason, it is only when the mothers have accepted this role reversal that an affective stability is achieved and the maternal-filial bond is restored.

Albeit the existence of this kind of punishment towards perverse and disorderly love, we could say that Mexican female writers who were born between the late 1960s and the late 1970s reflect in their writings a severe criticism of the mother and motherhood ideal that, as Palomar Verea states, responds to a vision of the type of social order that Mexico intends to establish (as it may occur in any other society) by means of the country's symbolic-cultural products like films and audiovisual productions, especially soap operas. Even so, literature written by women escapes such standardizing trends, as we have seen already, due to the long-standing literary tradition that provides female writers with this space of freedom. Without going further into this aspect, it will be sufficient to note that the small bastion of artistic freedom that female and male writers in Mexico benefit from allows them to address contentious issues openly, as in the present case. Also, despite they swim against the tide, recent female writers in Mexico continue to criticize the motherly ideal.

But, what about the younger female writers, those who were born in the 1980 s? Do they keep up with an open criticism towards the motherly ideal or are we facing a change of perspective? These questions are addressed in the following section.

\section{Awakening Text}

While pursuing our line of thought around literature written by women in Mexico, at this point we should note that the research corpus is composed by at least one piece of work of the following female writers: Valeria Luiselli, Gabriela Jáuregui, Laia Jufresa and Fernanda Melchor.

In nearly all of them, a negative portrait of the mother and motherhood is once more observed, except for a few exceptions that accentuate a different line by referring to such condition from a joyful view, opening a new way to approach this topic. This is the case of Daniela Rea, who openly talks about the being-mother from a joyful perspective, while still acknowledging the sacrifices involved in practicing motherhood.

Daniela Rea was born in Irapuato, Guanajuato, in 1982. She is a journalist, author of the book Nadie les pidió perdón: historias de impunidad y Resistencia [Nobody asked them for forgiveness. Stories of impunity and resistance] (2016), and Director of the film No sucumbió la eternidad [Eternity did not succumb] (2017), winner of the Breach Valdez journalism award. She is Co-founder both of Periodistas de a Pie (Ordinary journalists), organization with which she edited 
the book Entre las cenizas: historias de vida en tiempos de muerte [Among ashes. life stories in times of death] (2012), and of Pie de Página (Footnote), which is a network of journalists who are experts in human rights and social topics. Such network won the Gabriel García Márquez journalism award in 2017, with the documentary series Buscadores en un país de desaparecidos [Seekers in a country of missing people].

Among her texts, her memoirs in the form of an intimate journal "Mientras las niñas duermen" ["While the girls are asleep"] stand out. This work is part of the book Tsunami (2018), whose edition and prologue were in charge of Gabriela Jáuregui. In this work, Rea provides us with an intimate view on motherhood and its challenges. On her first entry on March $27^{\text {th }}, 2014$, she shares such view as follows: "We are born already, and happiness weights $3.5 \mathrm{~kg}$ and is $47 \mathrm{~cm}$ long. This day will last for a lifetime" (Rea, 2018: p. 121). This mother and daughter simultaneous double birth will mark the whole journal, as it is represented as some sort of awakening text that, different from what Rita Felski (1989) states in the novel of awakening, it does not end when the transformation begins, but it starts just after this transformation takes place. It is to say, different from the novel literary genre, in the journal, the feminist awakening seems to happen in the very moment the main character becomes a mother and, from there on, all other events that subordinate to this aspect, including the work-related aspects, will take place. Therefore, we could say that, in Rea's journal, the actions are initiated by this awakening that will gradually develop in every area until she positions herself as a woman-mother, free and happy to assume her motherly role and the consequences and implications such role entails. Yet, let us proceed with our analysis in a gradual way.

In the previous paragraph, we pointed out that the journal starts with the double birth of the mother-daughter binomial. The daughter herself is referred to as "happiness", and we are provided with the information of the weight and height of the child that brings such feelings of happiness and enjoyment to her mother. Moreover, the birth date will mark a turning point on the main character's sense of time as the syntagm "This day will last for a lifetime" suggests a milestone in the mother's life, which is received with delight or, at least, with enthusiasm.

Nonetheless, such state of happiness will not last for long, as in the following entry, dated as of April 2nd, an unexpected health problem makes the main character feel overwhelmed and concerned and all actions taken for the sake of preserving the newborn's life are described in detail: "We dressed you in a hurry. I wrapped you in a blanket, took you in my arms and ran down the three-floor staircase that keep our apartment away from the street. We ran to the hospital" (Rea, 2018: p. 121). The description of this second entry is made in a breathtaking way. It is a narrative technique that allows the readers to dive into the vortex of a medical emergency, making them part of the anxiety and unease of the main character. Despite the promptness with which the events are described, the main 
character has a moment of profound reflection as, amidst the medical agitation to make the baby react, she is capable of judging her own role and duty as a caring and protective mother by noting the following: "The doctors wanted to take me out of the room because they said I made you nervous. I told them not to, if there was something that could make you feel safe in this world, that was me, your mom" (Rea, 2018: p. 121). As it might be observed in this sentence, the physicians presume to know the feelings experienced by a baby that was born only two days before. For her part, and following the same reasoning of the physicians, the main character asserts her role as a mother, opposing to what the physicians state, namely, her presence, being her mother, makes the baby feel safe, and does not make her nervous, as the physicians say. Even when, apparently, the main character seems to have triumphed, such victory will soon be dashed, when the medical discourse and attention protocols force the main character and her husband to relinquish their wish to take their little one with them. Instead, they have to leave her at the hospital for several days, at the mercy of the medical staff. The child's continuous mourning makes the main character realize her ignorance before the baby's needs, resulting in her limiting to accept the facts and accept detachment: "Your dad and I objected but, in the end, left without you. We left hurt, comforting each other. You stayed, naked, in an incubator, crying because you were either hungry, cold, in pain, or scared, I don't know." (Rea, 2018: p. 122)

After this couple of entries, the narrator immerses us deeply in the world of motherhood. Its chaos, sacrifices, concerns, i.e., in everything linked to the fact of becoming a mother, a first-time mother (further on, when her second daughter is born, she emphasizes some aspects expressed in this first couple of entries). As a consequence, she also shows us the doubts, uncertainties and continuous thoughts around the meaning of becoming a mother. Even when it is true that she never loses the realistic sense of what motherhood and its practice mean, it is also true that the first feeling of happiness, as depicted above, prevails over the anguish and unease that continuously appears in the story. The landscape offered is, therefore, one of lights and shadows and, amidst happiness, becoming aware of such progressive conversion into a mother:

"APRIL 29"TH

I was not born a mother. I did not become a mother when you were born, either. I have become a mother gradually, whenever I wake up at night for you to drain my breasts, my blood, my energy. Whenever I cry, because you cry. Whenever I step out of the room, and leave you to cry, because I don't know how to soothe you. An also during the early mornings, like this one, when I managed to put you to sleep in my arms, and I am still alive." (Rea, 2018: p. 123)

And it's just out of that raise of awareness of what being a mother means, and the way in which such fact traverses gradually all action spheres in life, that we 
are able to say this is an awakening text. In so far as the main character continues to acquire a political stance before the practice of motherhood, undertaking it as it is, that is to say, a political claim before the discourses that cancel and try to abrogate the mother's presence in the different spaces of coexistence. We could therefore state that the fact of assuming herself as a mother, with all its implications, progressively becomes, throughout the journal, in a day-to-day, continuous and steady struggle to vindicate the mother role in all spaces, including public transportation and coffee shops, as we can read in the gloss of 2016:

What about our ability to decide? About deciding something in the small space of freedom we have left? [...] Each time we board a plane or bus, the passengers look at us as if we were infected [...], each time more, I find more pet-friendly restaurants than kind-friendly ones and I don't want this adult world to relegate myself and my daughter to the dark and solitary corner of our home. Yes, I would like to walk arm-freely again, not carrying a nappy bag and a girl [...], but I have also assumed that going out to the streets with my daughter is a political stand. (Rea, 2018: p. 133)

As we may observe, the main character slowly positions herself as a woman-mother, conquering for herself and her daughter a place within the different spaces where she normally moves and functions. Thus, a raise of awareness takes place which helps her practice her being a mother in all the spaces where, as we read in the quotation, result to be more pet-friendly than child-friendly as everything seems to be built for adults and with an androcentric approach that does not take into account the needs of mothers and their daughters and sons. So, the main character claims such spaces through her and her daughter's presence and, being looked with disdain, she assumes and practices her motherly role, trying to teach her daughter the sorority and solidary commitment among women: "She also comes with me because I would like her to learn to be a supportive and sensitive girl and I think my work as a journalist provides her with the opportunity to meet people that live different circumstances from hers." (Rea, 2018: p. 133)

The development of the ethical commitment to others arises when leading not by words but by example. Such premise seems to be embraced by the main character who, acting as a devoted mother, endeavors to bequeath her daughter with such ethical commitment towards less-favored people. The raise of consciousness is translated in education, with which the first narrative series is closed in order to welcome a second one that, among doubts and concerns, reflect the shift in paradigm around motherhood, as it is once more introduced to us as fulfilling and happy.

\section{Paradigm Shift: Joyful Motherhood}

This second narrative series, the most important for the subject matter before us, starts as we have seen already, with the first entry and continues, throughout the journal with the expectation and birth of the second daughter. Once again, and 
without setting aside the realistic approach of what being a mother represents, this second series recounts motherhood from the perspective of expectation, bliss, joy and other positive aspects that reinforce the semantic field of happiness. Thus, in the entry dated as of June $15^{\text {th }}, 2016$, the main character recounts how surprised she felt when she learned she was pregnant again, even when this fact still represents a cause of unease and fear before the actual possibility of being nullified as a person by this second daughter or son (at that moment in time she still does not know the baby's gender). Albeit her concern, at the end of the entry a positive, even flattering nuance is seen, when pointing out that the parents (father and mother) do not wither because of the children, instead, they bloom: “I've been crying non-stop for days. I am having another child and I feel as if such child would wipe the person I am. However, someone around me is listening and embraces me: you won't be erased. Our parents were not erased by us. They flourished.” (Rea, 2018: p. 135)

Just as in the first narrative series, the second one portrays lights and shadows but, different from the first one, the mood becomes far more intimate, as this second series submerges us even further in the family world and personal thoughts. While in the first series a more public tenor is perceived, throughout the second one the deepest thoughts around motherhood-related experiences are introduced, and the author shares family moments that allow us to plunge into that peaceful and pleasant environment motherhood represents. Even when the feminist raise of awareness around the being-mother continues to be present, it is also true that what stands out most in this second series is the subjective approach through memories or personal dialogues held with the main character's mother or with other female authors who, furthermore, are corrected by her when they share their insights on motherhood. Thus, it is not surprising that in this second part a series of apparent contradictions arise, between freedom and anchorage, and between professional work and upbringing and caring for her children. However, such contradictions successfully create a progress and backsliding atmosphere, allowing the reader to have a more complex and comprehensive insight of the meaning of the being-mother:

\section{JUNE $25^{\mathrm{TH}}$}

I read: A new alibi has been addressed towards women to attract them back to their homes. This backlashing instrument carries with it an old name: Children! Contra los hijos [Against children], by Lina Meruane.

No. We will not return home. We work and nurture at the boundaries. (Rea, 2018: p. 135)

Mom: I was not unhappy, I had you [...]. You fulfilled me because you were pretty, earnest students, charming. Everything else like sleeping late or washing was vague to me. (Rea, 2018: p. 136)

As we can observe, above nullification or physical exhaustion resulting from parenting, once more a positive and even kind perspective of motherhood is imposed. In such sense, Rea achieves balancing the acknowledgment of the 
hardships with the emotional and affective-joyful side of motherhood. Therefore, this second part is worth being highlighted as in the Mexican literature written by young women, such aspect is not considered from a critical perspective. Instead, as we have mentioned before, it is the first aspect that is alluded, from a critical stand. For this reason, the fact that Rea recovers the joyful side of motherhood leads us to think and suggest that a paradigm shift is emerging around how women from young generations (those born during the 1980s, 1990s and 2000s decades) are conceiving and living motherhood. Rea would then represent a significant rupture of the way in which young women experience being mothers nowadays, and even when we are conscious of the fact that one single proposal will not set a trend, we can deduct that there is something new that is emerging in such more recent generations, which leads them to accept that, among the hardships, in the end there is also joy, bliss and happiness when practicing motherhood:

It is thrilling to have you and Naira, and to walk down the street together, and proudly say "my girls".

DECEMBER $1^{\text {ST }}$

Motherhood is imposed, yes. The use of our bodies is a profit on capital, yes. The exploiting of our bodies is for taking care of manpower, yes. Patriarchy decides on our names, yes. All of that happens, yes. But, what about tenderness? What about that unfathomable feeling I experience when I smell you, when I look at you, when we caress each other? What about that desire to kiss you, to observe you? What about that sense of belonging when we hold each other until falling asleep? How can those things be explained? (Rea, 2018: p. 139)

For all of the above, I consider we are before a new form of motherhood appropriation. It has nothing to do with extreme idealization (so encouraged by the Golden Age of Mexican cinema), nor with sustained criticism (such a strong attribute of the generations born between the 1960s and the 1970s). It has to do with a deeper insight of what motherhood represents and of the way in which the being-mother is assumed, acknowledging its demands, without leaving aside positive aspects such as tenderness, affection, love. We are on the verge of a new paradigm, and we can only expect for its further development and strengthening, considering that, probably, the millennial generation is experiencing another way of interacting with this and other inter and intragender issues.

\section{And, What about Work?}

Finally, among the narrative series that conform the journal, we could say there is a third series, work-related. As discussed in previous paragraphs, motherhood does not cancel the opportunity to work: on the contrary, it is work (in this case, as a journalist) that opens a range of opportunities to teach and educate children from a moral and solidary commitment with others. Likewise, when linked to 
motherhood, all work performed from this being-mother perspective is transformed in a political tool through which every day spaces are claimed.

However, expanding on the alternation of showing the positive and negative aspects of motherhood, in this work-related series we can once more observe the chiaroscuro the main character goes through in such aspect. As in the first couple of narrative series, the main character suffers both the sleepless nights of child care and rearing, and the late deliveries of her texts as her two little ones demand attention: "AUGUST $3^{\text {RD }}$. It's not you, my daughter. It is tiredness, stress, backlog.” (Rea, 2018: p. 157)

The open and straight-forward acknowledgment of the most exhausting share of being a mother does not weaken the happiness feeling that runs through the main character. In fact, she repeats several times how happy and proud she is of being a mom expressing, once more, her mindful commitment towards her free decision-making on becoming a mother. Therefore, she assumes her work situation as an important, but not paramount, part of her life:

\section{FEBRUARY $17^{\mathrm{TH}}$}

The three of us are home, and you both have fever. I canceled my job. I closed the curtains and the room is dark. I lay between the both of you. With one hand, I caress you, Naira, and you are burning up in fever. You breathe like a wounded bird. With my other hand, I draw circles on your back, Emilia, on your breathless little lungs.

And yet, I feel good in here. Like this, between you, my offspring. (Rea, 2018: p. 153)

Finally, the dilemma that arises when the main character does not have read the text she was supposed to include in the book where the journal is published is solved through her decision of sharing her actual journal with the readers. Such decision allows the main character to become aware, once more, of a broader sense of community, as she reaffirms herself as a feminist by choosing to be a mother and to assume the tasks such choice entails. Reconsidering herself as a feminist from this free stance reflects an internal process that allows the main character to appreciate what she does from a deeper and broader perspective. In this text, motherhood and feminism are not opposed to one another, conversely, they complement each other:

JULY $8^{\text {TH }}$

Today, it is my birthday.

I always wanted to be a mother.

I remember when I was a kid and used to play mom with my dolls. (Rea, 2018: p. 148)

\section{AUGUST $16^{\mathrm{TH}}$}

I show the draft of this text to a female feminist friend [...] I don't feel embarrassed before the world, but before them, my daughters, who are being built. We build each other in our relationship. Sharing such embarrassment 
prevents it from being only mine. It is as if I swept it outside of the house.

(Rea, 2018: pp. 157-158)

As for work, in this case writing and publishing, in the end it comes to terms with motherhood and provides the main character with a sense of freedom that, once more, makes her happy: "Why have I written for 4 years? What for? [...] Maybe for them to be a bit freer. For us to be a little freer.” (Rea, 2018: p. 158)

\section{Conclusion}

All in all, in the text Mientras las niñas duermen [While the girls are asleep], Daniela Rea opens the gate to a realistic depiction of motherhood from a joyful and happy perspective, not leaving aside the most exhausting aspects of care and nurturing. In such a way, in her text, Rea achieves bringing together both sides of being a mother. She does it from a fulfillment perspective that makes her acknowledge that, far from obliterating their fathers and mothers, sons and daughters make them flourish.

Although it is true that the most adverse elements could, at some point, represent the object of attention in a more emphatic way, it is also true that Rea lifts that weight away from them by continuously opposing the happiness and fulfillment the main character feels when recognizing and assuming in a conscious and free way the commitment of becoming the mother of her two daughters. For this reason, Rea's text is considered to unveil a new line to approach the motherhood phenomenon within the literature written by women in Mexico, as it deviates from the pessimism and severe criticism her predecessors have posed in their writings. Hence, we reckon being before a paradigm shift that exhibits a path around the woman-mother that is way more complex and profound.

Henceforth, Daniela Rea positions herself as a voice that is different and worthy of being closely studied, as she attains combining the raise of awareness and social engagement with the family, household, intimate world. For now, we must expect that such voice continues to be strengthened and let herself be heard, clearly and forcefully, in her future pieces of work.

\section{Conflicts of Interest}

The author declares no conflicts of interest regarding the publication of this paper.

\section{References}

Badinter, E. (1981). ¿Existe el amor maternal? Historia del amor maternal. Siglos XVII al XX [Mother Love: Myth and Reality. Motherhood in Modern History Tran.]. Marta Vassallo, Barcelona: Paidós/Pomaire.

Bergman, E. L. (1995). "Mujer y lenguaje en los siglos XVI y XVII: Entre humanistas y Bárbaros" ['Woman and Language in the 16th and 17th Centuries: Among Humanists and Barbarians'] in Record XII (pp. 33-41). AIH, Spain: Cervantes Virtual Center.

Eudave, C. (2008). Bestiaria vida ['Bestriary Life']. Yucatán, Mexico: Ficticia Editorial/Institute of Culture, Yucatán. 
Felski, R. (1989). Beyond Feminist Aesthetics. New York: New York University Press.

Guevara del Ángel, I. (2008). Santas madrecitas [Holy Little Mothers]. Mexico: Fondo Editorial Tierra Adentro.

Habermas, J. (2008). El discurso filosófico de la modernidad. [The Philosophical Discourse of Modernity Tran.]. Manuel Jiménez Redondo, Madrid: Katz Editores. https://doi.org/10.2307/j.ctvm7bdhv

López González, A. (1995). Sin imágenes falsas, sin falsos espejos. Narradoras mexicanas del Siglo XX [Without False Images, without False Mirrors: Mexican Female Narrators of the 20th Century]. Mexico: El Colegio de México. https://doi.org/10.2307/j.ctvhn0cm7

Oyarzún, K. (1995). “Identidad femenina, genealogía mítica, historia: Las manos de mamá" ['Feminine Identity, Mythical Genealogy, History: Mom’s Hands]. In A. López González (Coord.), Sin imágenes falsas, sin falsos espejos. Narradoras mexicanas del siglo XX. [Without False Images, without False Mirrors: Mexican Female Narrators of the 20th Century] (pp. 51-75). Mexico: El Colegio de México.

https://doi.org/10.2307/j.ctvhn0cm7.5

Palomar Verea, C. (2007). Maternidades en prisión [Motherhoods in Prison]. Guadalajara, Mexico: University of Guadalajara.

Rea, D. (2018). “Mientras las niñas duermen” ['While the Girls Are Asleep']. In G. Jáuregui (Ed.), Tsunami (pp. 119-158). Mexico: Sexto piso. 